\title{
How To Diagnose and Treat Hepatitis B Virus Antiviral Drug Resistance in the Liver Transplant Setting
}

\author{
Anna S. F. Lok \\ University of Michigan, Ann Arbor, Ml \\ Received May 8, 2008; accepted July 21, 2008.
}

\section{Key Points}

1. Hepatitis B virus variants with antiviral drug-resistant mutations and/or hepatitis B immune globulin-resistant mutations are the main cause of hepatitis B virus reinfections post-liver transplant.

2. Early diagnosis of antiviral drug resistance and prompt initiation of rescue therapy are important in preventing hepatitis flares and hepatic decompensation.

3. Virologic breakthrough is the first indication of antiviral drug resistance.

4. Genotypic resistance testing should be performed when possible to avoid unnecessary modification of treatment in patients who do not have confirmed antiviral drug resistance and to permit appropriate selection of rescue therapy in those who have confirmed antiviral drug resistance.

5. Choice of rescue therapy requires knowledge of the past history of hepatitis B virus treatments and virologic response to those treatments, patterns of mutations detected at the time of virologic breakthrough, and in vitro cross-resistance data.

6. Occurrence of antiviral drug resistance can be reduced by the use of the most potent nucleos(t)ide analogue(s) with the highest genetic barrier to resistance, emphasis of medication compliance, and close monitoring of virologic response. Liver Transpl 14:S8-S14, 2008. (1) 2008 AASLD.

The availability of orally administered nucleos(t)ide analogues that are safe and effective in suppressing hepatitis $B$ virus (HBV) replication in pre- and postliver transplant patients has revolutionized the man- agement of these patients. However, these therapies do not eradicate HBV. Therefore, most patients require long-term treatment to maintain virus suppression. Life-long treatment is generally recommended for liver transplant patients to prevent hepatitis flares associated with virologic relapse because these flares may lead to rapid decompensation and death in patients who have limited hepatic reserve or are immunosuppressed, but the risk of antiviral drug resistance increases with the duration of treatment. Thus, while the use of nucleos(t)ide analogues pre-transplant and combination of nucleos(t)ide analogues and hepatitis B immune globulin (HBIG) post-transplant have been shown to reduce the rate of $\mathrm{HBV}$ reinfection post-transplant to less than 10\%, almost all cases of HBV reinfection are due to HBV variants with antiviral drug-resistant mutations and/or HBIG-resistant mutations. ${ }^{1-3}$ This review discusses the nomenclature, diagnosis, treatment, and prevention of $\mathrm{HBV}$ antiviral drug resistance.

\section{NOMENCLATURE}

Antiviral drug resistance may be reported as phenotypic resistance, genotypic resistance, viral resistance, or clinical resistance. Table 1 summarizes the definitions of the most common terms used to describe antiviral drug resistance. ${ }^{4}$ Phenotypic resistance is defined as decreased susceptibility (ie, increased concentrations of the drug are needed to achieve $50 \%$ or $90 \%$ inhibition) of an HBV polymerase to an antiviral drug in in vitro assays. Genotypic resistance is defined as the detection during antiviral therapy of viral populations

Abbreviations: HBIG, hepatitis B immune globulin; HBV, hepatitis B virus; MALDI-TOF, matrix-assisted laser desorption/ionization time-of-flight; RFLP, restriction fragment length polymorphism.

Address reprint requests to Anna S. F. Lok, M.D., Division of Gastroenterology, University of Michigan Hospitals, 3912 Taubman Center, SPC 5362 , Ann Arbor, MI 48109. FAX: 734-936-7392; E-mail: aslok@med.umich.edu

DOI 10.1002/lt.21616

Published online in Wiley InterScience (www.interscience.wiley.com). 
TABLE 1. Nomenclature for Antiviral Resistance

\begin{tabular}{lr}
\hline Term & Definition \\
\hline Virologic breakthrough & $\begin{array}{r}\text { Increase in serum HBV DNA by }>1 \log _{10} \text { above nadir } \\
\text { while patient is on treatment after achieving initial } \\
\text { response }\end{array}$ \\
Biochemical breakthrough & $\begin{array}{r}\text { Increase in serum alanine aminotransferase while patient } \\
\text { is on treatment after achieving initial response } \\
\text { Genotypic resistance }\end{array}$ \\
Phenotypic resistance & $\begin{array}{r}\text { Detion of amino acid substitutions in the reverse } \\
\text { transeriptase region of the HBV polymerase gene that has } \\
\text { been shown to decrease susceptibility to treatment } \\
\text { In vitro confirmation that the mutation decreases } \\
\text { susceptibility to treatment }\end{array}$ \\
\hline Abbreviation: HBV, hepatitis B virus. &
\end{tabular}

bearing amino acid substitutions in the reverse transcriptase region of the HBV polymerase gene that have been shown to confer resistance to antiviral drugs in phenotypic assays. Viral resistance or virologic breakthrough is defined as an increase in serum HBV DNA by at least $1 \log _{10}(10$-fold) above nadir or the reappearance of serum HBV DNA in the patient with previously undetectable HBV DNA on $\geq 2$ occasions at least 1 month apart while the patient is on treatment and after initial response is achieved in the medication-compliant patient. The term clinical resistance is often used synonymously with biochemical breakthrough and is defined as an elevation in serum alanine aminotransferase while the patient is on treatment and after normalization is achieved in the medication-compliant patient. Ascertainment of medication compliance is problematic because assays for monitoring nucleo$\mathrm{s}(\mathrm{t})$ ide drug concentrations are not readily available and self-reporting by patients may not be reliable. As many as $30 \%$ to $50 \%$ of virologic breakthroughs observed in clinical trials are attributed to noncompliance with medications ${ }^{5-8}$; this figure is likely higher in clinical practice.

\section{DIAGNOSIS}

Genotypic resistance may precede viral resistance (virologic breakthrough) by many months, and viral resistance may precede clinical resistance (biochemical breakthrough) by months to years. Because of the potential devastating effect of biochemical breakthrough in liver transplant patients, early diagnosis of antiviral drug resistance and prompt intervention are critical. Thus, confirmation of virologic breakthrough on repeat testing is not necessary if there is a marked increase in serum HBV DNA or if there is accompanying biochemical breakthrough.

Detection of virologic breakthrough requires knowledge of the pretreatment serum HBV DNA level, documentation of initial response, determination of nadir or lowest HBV DNA level achieved, and detection of $a \geq 1$ $\log _{10}$ increase (or reappearance) in the HBV DNA level. Therefore, establishment of the baseline serum HBV DNA level and regular monitoring, preferably at 3-month intervals with the same HBV DNA assay at each measure, are necessary for the diagnosis of viral resistance. Without documentation of initial response, it is not possible to determine if a patient who has a high serum HBV DNA level after a long duration ( $\geq 6$ months) of nucleos(t)ide analogue therapy has never achieved adequate viral suppression or instead has virologic breakthrough. This is particularly problematic for patients receiving adefovir, which has weak antiviral activity at the approved dose.

Because not all breakthroughs are due to drug resistance, confirmation with genotypic resistance testing should be performed whenever possible. This will avoid unnecessary modification of treatment in patients who do not have confirmed antiviral drug resistance and permit appropriate selection of rescue therapy in those who have confirmed antiviral drug resistance. Genotypic resistance testing is particularly important in guiding the choice of rescue therapy for patients who have been exposed to more than 1 nucleos(t)ide analogue as multidrug resistance mutants have been reported in patients who have received sequential monotherapies. ${ }^{9-11}$

A variety of assays have been used for the detection of HBV antiviral drug-resistant mutations (Table 2). Direct (population) sequencing is the least sensitive method for detecting minor populations of drug resistance mutants. This method requires that the mutant population composes approximately $20 \%$ of the total HBV quasispecies pool for detection. However, direct sequencing allows all mutations to be identified, and this is important when we are evaluating resistance to new therapies for which the full spectrum of resistant mutations has not been determined and when we are evaluating drug resistance in patients who have received multiple nucleos(t)ide analogues. Other assays such as restriction fragment length polymorphism and reverse hybridization (line probe) assays can detect viral mutants that constitute as little as $5 \%$ of the total viral population. ${ }^{12,13}$ Because these assays are more sensitive, they enable earlier identification of patients with genotypic resistance ${ }^{14,15}$ and may be particularly useful in the management of liver transplantation patients. A major disadvantage of these assays is that they 


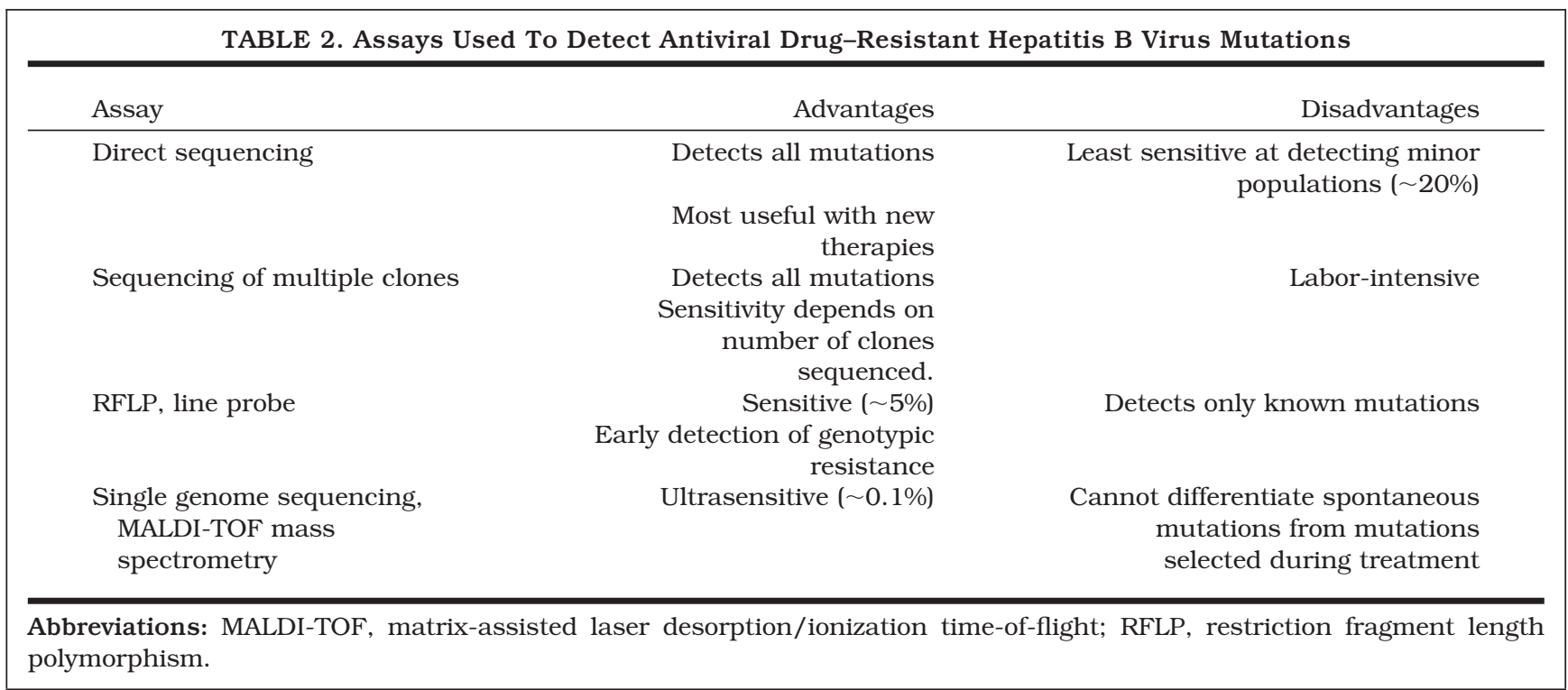

\begin{tabular}{|c|c|c|}
\hline \multicolumn{3}{|l|}{ Nucleos(t)ide } \\
\hline Analogue & Mutation & Comment \\
\hline \multirow[t]{3}{*}{ Lamivudine } & M204V/I & Resistance \\
\hline & $\mathrm{A} 181 \mathrm{~T}$ & Resistance \\
\hline & L80, V173L, L180M & Compensatory \\
\hline \multirow[t]{2}{*}{ Telbivudine } & M204I & Resistance \\
\hline & L80, L180M & Compensatory \\
\hline \multirow[t]{3}{*}{ Adefovir } & A181V or $\mathrm{N} 236 \mathrm{~T}$ & Resistance \\
\hline & A181T & Resistance \\
\hline & I $233 \mathrm{~V}$ & Primary nonresponse* \\
\hline \multirow[t]{3}{*}{ Entecavir } & $\mathrm{T} 184 \mathrm{~S} / \mathrm{A} / \mathrm{I} / \mathrm{L} / \mathrm{F} / \mathrm{G} / \mathrm{M} / \mathrm{C}$ & Resistance $\dagger$ \\
\hline & $\mathrm{S} 202 \mathrm{G} / \mathrm{C}$ & Resistance $\dagger$ \\
\hline & M250V/L/I & Resistance $\dagger$ \\
\hline Tenofovir & A194T & Resistance* \\
\hline
\end{tabular}

can detect only known mutations, and existing assays may not detect all mutations that have been shown to be associated with resistance to HBV antiviral drugs. Recently, several ultrasensitive assays, such as single genome sequencing and mass spectrometry-based restriction fragment mass polymorphism, which can detect mutants that constitute $<0.1 \%$ of the viral quasispecies, have been used to detect antiviral drug-resistant HBV mutations, ${ }^{16,17}$ but the utility of these ultrasensitive assays in predicting viral resistance and the need for modification of treatment has not been established.

\section{MUTATIONS ASSOCIATED WITH RESISTANCE TO NUCLEOS(T)IDE ANALOGUE THERAPIES}

Mutations associated with antiviral resistance may be classified as primary (being responsible for decreased susceptibility to the drug) or compensatory (being responsible for restoring replication fitness of the mutant virus). Signature mutations associated with resistance to the approved HBV therapies have been characterized (Table 3). ${ }^{4}$ As an increasing number of patients with divergent HBV sequences are exposed to nucleos(t)ide analogue therapies, additional mutations may be identified. However, caution must be exercised in attributing differences in HBV sequences as the cause of antiviral drug resistance, particularly when baseline sequences are not available for comparison. Thus, the significance of several mutations such as alanine-tothreonine substitution at position 181 (rtA181T) and resistance to adefovir, isoleucine-to-valine substitution at position 233 (rtI233V) and primary nonresponse to adefovir, and alanine-to-threonine substitution at position 194 (rtA194T) and resistance to tenofovir remains controversial. ${ }^{18-21}$

Among nucleoside-naïve patients, antiviral drug resistance has been reported in up to $70 \%$ of patients after 4 years of lamivudine, 29\% after 5 years of adefo- 
TABLE 4. Treatment Options for Patients with Antiviral Resistance

Type of Resistance

Lamivudine or telbivudine resistance

Adefovir resistance*

Entecavir resistance*

Multidrug resistance
Rescue Therapy

Add adefovir or tenofovir.

Switch to emtricitabine and tenofovir. Add lamivudine or switch to emtricitabine and tenofovir. Add entecavir. Add adefovir or tenofovir.

* Limited in vivo data.

vir, $1 \%$ after 5 years of entecavir, and $9 \%$ to $22 \%$ after 2 years of telbivudine. ${ }^{22-25}$ Resistance rates are substantially higher in patients with prior resistance to lamivudine, with rates of up to $20 \%$ after 2 years of switching to adefovir monotherapy and 51\% after 5 years of switching to entecavir. ${ }^{25,26}$

\section{TREATMENT OF PATIENTS WITH ANTIVIRAL DRUG-RESISTANT HBV}

Optimal management of patients with antiviral drugresistant $\mathrm{HBV}$ requires knowledge of the past history of HBV treatments and virologic response to those treatments, patterns of mutations detected at the time of virologic breakthrough, and in vitro crossresistance data. Rescue therapy should be initiated early when virologic breakthrough is confirmed to be due to drug resistance. ${ }^{27}$ If genotypic resistance testing is not readily available, rescue therapy should be initiated in patients who have virologic breakthrough despite medication compliance. Options for rescue therapy against antiviral drug-resistant HBV are listed in Table $4 .{ }^{4,28}$

\section{Lamivudine and telbivudine resistance}

Lamivudine and telbivudine are L-nucleosides that select for mutations at the same site: methinone to valine or isoleucine at position 204 (rtM204V/I) for lamivudine and only rtM204I for telbivudine. In vitro studies demonstrated that adefovir, tenofovir, and entecavir have antiviral activity against rtM204V/I. The antiviral activity of adefovir against rtM204V/I is comparable to its activity against wild-type $\mathrm{HBV}$, but its activity against rtA181T appears to be lower. ${ }^{29,30} \mathrm{~A}$ pilot study in patients with lamivudine-resistant HBV reported that adefovir monotherapy resulted in similar rates of viral suppression when compared with combination therapy of lamivudine and adefovir. ${ }^{31}$ However, the combination of lamivudine plus adefovir has been shown to be more effective in preventing adefovir resistance than adefovir monotherapy. ${ }^{32,33}$

In a study of 467 pretransplant and posttransplant patients who received additional adefovir for lamivudine-resistant HBV, serum HBV DNA became undetectable in 59\% of wait-listed patients and $40 \%$ of posttransplant patients after 48 weeks of treatment. ${ }^{34}$ Nephrotoxicity, defined as a confirmed increase in serum creatinine by $\geq 0.5 \mathrm{mg} / \mathrm{dL}$ from baseline, was ob- served in $6 \%$ of wait-listed patients, $47 \%$ of patients who underwent liver transplantation during the course of the study, and $21 \%$ of posttransplant patients. Many patients were receiving concomitant nephrotoxic medications, and some developed hepatorenal syndrome during the course of the study; thus, it is difficult to determine the role of adefovir in the worsening of renal function in these patients. In this study, only 9 patients had a confirmed decrease in serum phosphorus to $<2$ $\mathrm{mg} / \mathrm{dL}$. Serum creatinine should be closely monitored in all liver transplant patients receiving adefovir (and tenofovir), and dose adjustments should be made according to renal function.

Tenofovir has also been shown to be effective in suppressing lamivudine-resistant $\mathrm{HBV}$ in clinical studies. ${ }^{35,36}$ At the approved dose of $300 \mathrm{mg}$ daily, tenofovir has more potent antiviral activity than $10 \mathrm{mg}$ of adefovir and a similar safety profile. ${ }^{37-40}$

The activity of entecavir against lamivudine-resistant HBV is significantly lower than its activity against wildtype HBV, and the presence of an rtM204V/I mutation decreases the genetic barrier to entecavir resistance. ${ }^{41}$ Clinical studies showed that despite the use of a higher dose ( 1.0 versus $0.5 \mathrm{mg} /$ day in patients without lamivudine resistance), a 48-week course of entecavir suppressed serum HBV DNA to undetectable levels in a smaller percentage of hepatitis $\mathrm{B}$ e antigen-positive lamivudine-refractory patients (19\% versus 67\%), and continued treatment for up to 5 years resulted in a higher rate of entecavir resistance (50\% versus $1 \%$ after 5 years of treatment) in comparison with nucleos(t)ide naïve patients. ${ }^{25,42}$

The best approach for patients with lamivudine resistance is to continue lamivudine and add adefovir. In patients with suboptimal viral suppression and those with the rtA181T mutation, tenofovir may be substituted for adefovir. Tenofovir should replace adefovir when it is approved for HBV treatment because it has more potent antiviral activity. Entecavir is not an optimal treatment for lamivudine-refractory patients because of the high risk of subsequent entecavir resistance. This same approach can be applied to patients with telbivudine resistance.

\section{Adefovir resistance}

In vitro studies have demonstrated that lamivudine, telbivudine, and entecavir all have antiviral activity 
against adefovir-resistant mutations, but the activity of lamivudine (and likely telbivudine) against the rtA181V/T mutation is lower in comparison with wildtype HBV. ${ }^{43}$

Clinical data regarding rescue therapy for patients with adefovir-resistant HBV are limited. Case reports have suggested that lamivudine is effective in suppressing serum HBV DNA levels in patients with adefovir resistance. ${ }^{44,45}$ However, the durability of response, particularly in patients with previous lamivudine resistance, is unknown. Furthermore, re-emergence of lamivudine-resistant mutations in this population has been observed within a few months of the reintroduction of lamivudine. ${ }^{11}$ Tenofovir has been reported to result in decreases in serum HBV DNA levels in patients with adefovir-resistant HBV, possibly because of the higher dose used: $300 \mathrm{mg}$ versus $10 \mathrm{mg}$ for adefovir. However, the efficacy of tenofovir monotherapy in this setting is limited because of cross-resistance between tenofovir and adefovir. ${ }^{46,47}$ Entecavir has been shown in case reports to be effective in suppressing adefovir-resistant $\mathrm{HBV}^{26}$

The best approach to treating patients with adefovir resistance is to add lamivudine, telbivudine, or entecavir (Table 4). Entecavir may be a better option for patients with previous lamivudine resistance and in patients with the $\mathrm{rtA} 181 \mathrm{~V} / \mathrm{T}$ mutation.

\section{Entecavir resistance}

Resistance to entecavir occurs through a 2-hit mechanism. ${ }^{41}$ Initially, HBV with an rtM204V/I mutation is selected because these mutants are less sensitive to entecavir in comparison with wild-type HBV. Virologic breakthrough occurs only after the emergence of additional entecavir resistance mutations at codons 184, 202, and 250. Entecavir resistance mutations are sensitive to adefovir and tenofovir in vitro, but in vivo data supporting their efficacy are based on isolated case reports only. ${ }^{26,48,49}$

The only option for treating patients with entecavir resistance is to add adefovir or tenofovir (Table 4).

\section{$\mathrm{HBIG}$ resistance}

Mutations in the hepatitis B surface protein have been detected in patients who developed HBV reinfection after liver transplantation despite HBIG prophylaxis. The most common mutation involves glycine-to-arginine substitution at position 145 (sG145R). ${ }^{50}$ Lamivudine has been shown to be effective in suppressing serum HBV DNA levels in posttransplant patients who received HBIG prophylaxis only and who developed recurrent hepatitis $B .^{51,52}$ It is likely that other HBV nucleo$\mathrm{s}(\mathrm{t})$ ide analogues have similar efficacy.

\section{Multidrug resistance}

Sequential treatment with nucleos(t)ide analogue monotherapy has resulted in the sequential selection of mutations conferring resistance to both the initial and subsequent rescue therapy. ${ }^{10,11}$ Combinations of mutations to antiviral drugs and HBIG have also been reported in liver transplant recipients who received antiviral therapy and HBIG prophylaxis. ${ }^{9}$ The best approach to treating patients with multidrug resistance is unclear. Careful characterization of the pattern of mutations is needed to guide the choice of rescue therapy in these patients.

\section{CONCLUSIONS}

Antiviral drug resistance is the most important cause of HBV reinfection after liver transplantation; therefore, every effort must be made to prevent its occurrence. Initial therapy should use the most potent nucleos(t)ide analogue with the highest genetic barrier to resistance, and the importance of medication compliance should be emphasized. Response should be closely monitored, and modification of treatment should be considered in patients who fail to achieve rapid virus suppression. Combination therapy with another drug that is not cross-resistant should be used if antiviral drugs with a low genetic barrier to resistance such as lamivudine or telbivudine or drugs with weak antiviral activity such as adefovir are used in liver transplant patients. Whether de novo combination therapy offers any advantage compared to monotherapy with potent drugs that have a high genetic barrier to resistance remains to be tested.

\section{REFERENCES}

1. Gane EJ, Angus PW, Strasser S, Crawford DH, Ring J, Jeffrey GP, McCaughan GW. Lamivudine plus low-dose hepatitis B immunoglobulin to prevent recurrent hepatitis B following liver transplantation. Gastroenterology 2007; 132:931-937.

2. Coffin CS, Terrault NA. Management of hepatitis B in liver transplant recipients. J Viral Hepat 2007;14(suppl 1):3744.

3. Sharma P, Lok A. Viral hepatitis and liver transplantation. Semin Liver Dis 2006;26:285-297.

4. Lok AS, Zoulim F, Locarnini S, Bartholomeusz A, Ghany MG, Pawlotsky JM, et al. Antiviral drug-resistant HBV: standardization of nomenclature and assays and recommendations for management. Hepatology 2007;46:254-265.

5. Lai CL, Chien RN, Leung NW, Chang TT, Guan R, Tai DI, et al. A one-year trial of lamivudine for chronic hepatitis B. Asia Hepatitis Lamivudine Study Group. N Engl J Med 1998;339:61-68.

6. Lai CL, Gane E, Liaw YF, Hsu CW, Thongsawat S, Wang Y, et al. Telbivudine versus lamivudine in patients with chronic hepatitis B. N Engl J Med 2007;357:2576-2588.

7. Dienstag JL, Schiff ER, Wright TL, Perrillo RP, Hann HW, Goodman $Z$, et al. Lamivudine as initial treatment for chronic hepatitis B in the United States. N Engl J Med 1999;341:1256-1263.

8. Colonno RJ, Rose R, Baldick CJ, Levine S, Pokornowski K, $\mathrm{Yu} \mathrm{CF}$, et al. Entecavir resistance is rare in nucleoside naive patients with hepatitis B. Hepatology 2006;44:16561665.

9. Bock CT, Tillmann HL, Torresi J, Klempnauer J, Locarnini S, Manns MP, Trautwein C. Selection of hepatitis B virus polymerase mutants with enhanced replication by lamivudine treatment after liver transplantation. Gastroenterology $2002 ; 122: 264-273$ 
10. Villet S, Pichoud C, Villeneuve JP, Trepo C, Zoulim F. Selection of a multiple drug-resistant hepatitis B virus strain in a liver-transplanted patient. Gastroenterology 2006;131:1253-1261.

11. Yim HJ, Hussain M, Liu Y, Wong SN, Fung SK, Lok AS. Evolution of multi-drug resistant hepatitis B virus during sequential therapy. Hepatology 2006;44:703-712.

12. Allen MI, Deslauriers M, Andrews CW, Tipples GA, Walters KA, Tyrrell DL, et al. Identification and characterization of mutations in hepatitis B virus resistant to lamivudine. Lamivudine Clinical Investigation Group. Hepatology 1998;27:1670-1677.

13. Kim HS, Han KH, Ahn SH, Kim EO, Chang HY, Moon MS, et al. Evaluation of methods for monitoring drug resistance in chronic hepatitis B patients during lamivudine therapy based on mass spectrometry and reverse hybridization. Antivir Ther 2005;10:441-449.

14. Lok AS, Zoulim F, Locarnini S, Mangia A, Niro G, Decraemer $\mathrm{H}$, et al. Monitoring drug resistance in chronic hepatitis $B$ virus (HBV)-infected patients during lamivudine therapy: evaluation of performance of INNO-LiPA HBV DR assay. J Clin Microbiol 2002;40:3729-3734.

15. Hussain M, Fung S, Libbrecht E, Sablon E, Cursaro C, Andreone P, Lok AS. Sensitive line probe assay that simultaneously detects mutations conveying resistance to lamivudine and adefovir. J Clin Microbiol 2006;44:1094-1097.

16. Kirishima T, Okanoue T, Daimon Y, Itoh Y, Nakamura $H$, Morita A, et al. Detection of YMDD mutant using a novel sensitive method in chronic liver disease type B patients before and during lamivudine treatment. J Hepatol 2002; 37:259-265.

17. Hong SP, Kim NK, Hwang SG, Chung HJ, Kim S, Han JH, et al. Detection of hepatitis B virus YMDD variants using mass spectrometric analysis of oligonucleotide fragments. J Hepatol 2004;40:837-844.

18. Borroto-Esoda K, Miller MD, Arterburn S. Pooled analysis of amino acid changes in the HBV polymerase in patients from four major adefovir dipivoxil clinical trials. J Hepatol 2007;47:492-498.

19. Lacombe K, Ollivet A, Gozlan J, Durantel S, Tran N, Girard PM, Zoulim F. A novel hepatitis B virus mutation with resistance to adefovir but not to tenofovir in an HIV-hepatitis B virus-co-infected patient. AIDS 2006;20:22292231.

20. Curtis M, Zhu Y, Borroto-Esoda K. Hepatitis B virus containing the I233V mutation in the polymerase reversetranscriptase domain remains sensitive to inhibition by adefovir. J Infect Dis 2007; 196:1483-1486.

21. Delaney WE, Ray AS, Yang H, Qi X, Xiong S, Zhu Y, Miller $\mathrm{MD}$. Intracellular metabolism and in vitro activity of tenofovir against hepatitis B virus. Antimicrob Agents Chemother 2006;50:2471-2477.

22. Lok AS, Lai CL, Leung N, Yao GB, Cui ZY, Schiff ER, et al. Long-term safety of lamivudine treatment in patients with chronic hepatitis B. Gastroenterology 2003;125:17141722 .

23. Hadziyannis SJ, Tassopoulos NC, Heathcote EJ, Chang TT, Kitis G, Rizzetto M, et al. Long-term therapy with adefovir dipivoxil for HBeAg-negative chronic hepatitis B for up to 5 years. Gastroenterology 2006;131:1743-1751.

24. Lai CL, Gane E, Hsu CW, Thongsawat S, Wang YM, Chen YG, et al. Two-year results from the globe trial in patients with hepatitis B: greater clinical and antiviral efficacy for telbivudine (LDT) vs. lamivudine. Hepatology 2006;44:222A.

25. Tenney DJ, Pokorowski KA, Rose RE, Baldick CJ, Eggers BJ, Fang J, et al. Entecavir at five years shows long longterm maintenance of high genetic barrier to hepatitis $B$ virus resistance. Paper presented at: Conference of the Asia-Pacific Association for the Study of the Liver (APASL); 2008; Seoul, Korea.
26. Fung SK, Chae HB, Fontana RJ, Conjeevaram H, Marrero $\mathrm{J}$, Oberhelman $\mathrm{K}$, et al. Virologic response and resistance to adefovir in patients with chronic hepatitis B. J Hepatol 2006;44:283-290.

27. Lampertico $\mathrm{P}$, Vigano $\mathrm{M}$, Manenti E, Iavarone M, Lunghi G, Colombo M. Adefovir rapidly suppresses hepatitis B in HBeAg-negative patients developing genotypic resistance to lamivudine. Hepatology 2005;42:1414-1419.

28. Lok AS, McMahon BJ. Chronic hepatitis B. Hepatology 2007;45:507-539.

29. Qi X, Xiong S, Yang H, Miller M, Delaney WE. In vitro susceptibility of adefovir-associated hepatitis B virus polymerase mutations to other antiviral agents. Antivir Ther 2007; 12:355-362.

30. Villet S, Pichoud C, Billioud G, Barraud L, Durantel S, Trepo C, Zoulim F. Impact of hepatitis B virus rtA181V/T mutants on hepatitis B treatment failure. J Hepatol 2008; 48:747-755.

31. Peters MG, Hann HH, Martin P, Heathcote EJ, Buggisch P, Rubin R, et al. Adefovir dipivoxil alone or in combination with lamivudine in patients with lamivudine-resistant chronic hepatitis B. Gastroenterology 2004;126:91-101.

32. Rapti I, Dimou E, Mitsoula P, Hadziyannis SJ. Adding-on versus switching-to adefovir therapy in lamivudine-resistant HBeAg-negative chronic hepatitis B. Hepatology 2007;45:307-313.

33. Lampertico P, Vigano M, Manenti E, Iavarone M, Sablon E, Colombo M. Low resistance to adefovir combined with lamivudine: a 3-year study of 145 lamivudine-resistant hepatitis B patients. Gastroenterology 2007;133:14451451.

34. Schiff E, Lai CL, Hadziyannis S, Neuhaus P, Terrault N, Colombo M, et al. Adefovir dipivoxil for wait-listed and post-liver transplantation patients with lamivudine-resistant hepatitis B: final long-term results. Liver Transpl 2007; 13:349-360.

35. Kuo A, Dienstag JL, Chung RT. Tenofovir disoproxil fumarate for the treatment of lamivudine-resistant hepatitis B. Clin Gastroenterol Hepatol 2004;2:266-272.

36. Peters MG, Andersen J, Lynch P, Liu T, Alston-Smith B, Brosgart CL, et al. Randomized controlled study of tenofovir and adefovir in chronic hepatitis B virus and HIV infection: ACTG A5127. Hepatology 2006;44:1110-1116.

37. van Bommel F, Wunsche T, Mauss S, Reinke P, Bergk A, Schurmann D, et al. Comparison of adefovir and tenofovir in the treatment of lamivudine-resistant hepatitis B virus infection. Hepatology 2004;40:1421-1425.

38. van Bommel F, Zollner B, Sarrazin C, Spengler U, Huppe $\mathrm{D}$, Moller $\mathrm{B}, \mathrm{t}$ al. Tenofovir for patients with lamivudineresistant hepatitis $B$ virus (HBV) infection and high HBV DNA level during adefovir therapy. Hepatology 2006;44: 318-325.

39. Heathcote J, Gane E, DeMan R, Lee S. A randomized, double-blind, comparison of tenofovir df (TDF) versus adefovir dipivoxil (ADV) for the treatment of $\mathrm{HBeAg}$ positive chronic hepatitis B (CHB): study GS-US-174-0103. Hepatology 2007;46:231A.

40. Marcellin P, Buti M, Krastev Z, Germanidis G. A randomized, double-blind, comparison of tenofovir (TDF) versus adefovir dipivoxil (ADV) for the treatment of HBeAg negative chronic hepatitis B (CHB): study GS-US-174-0102. Hepatology 2007;46:80A.

41. Tenney DJ, Levine SM, Rose RE, Walsh AW, Weinheimer SP, Discotto L, et al. Clinical emergence of entecavir-resistant hepatitis B virus requires additional substitutions in virus already resistant to lamivudine. Antimicrob Agents Chemother 2004;48:3498-3507.

42. Sherman M, Yurdaydin C, Sollano J, Silva M, Liaw YF, Cianciara J, et al. Entecavir for treatment of lamivudine- 
refractory, HBeAg-positive chronic hepatitis B. Gastroenterology 2006;130:2039-2049.

43. Yeh CT, Chien RN, Chu CM, Liaw YF. Clearance of the original hepatitis B virus YMDD-motif mutants with emergence of distinct lamivudine-resistant mutants during prolonged lamivudine therapy. Hepatology 2000;31:13181326.

44. Angus P, Vaughan R, Xiong S, Yang H, Delaney W, Gibbs $\mathrm{C}$, et al. Resistance to adefovir dipivoxil therapy associated with the selection of a novel mutation in the HBV polymerase. Gastroenterology 2003; 125:292-297.

45. Villeneuve JP, Durantel D, Durantel S, Westland C, Xiong $\mathrm{S}$, Brosgart CL, et al. Selection of a hepatitis B virus strain resistant to adefovir in a liver transplantation patient. J Hepatol 2003;39:1085-1089.

46. Tan J, Degertekin B, Wong SN, Husain M, Oberhelman K, Lok AS. Tenofovir monotherapy is effective in hepatitis B patients with antiviral treatment failure to adefovir in the absence of adefovir-resistant mutations. J Hepatol 2008; 48:391-398.

47. Van Bömmel F, Trojan J, Feucht H, Möller B. Tenofovir shows limited efficacy in treatment of HBV infections resistant against adefovir. Hepatology 2007;46:664A.
48. Yang H, Qi X, Sabogal A, Miller M, Xiong S, Delaney WE. Cross-resistance testing of next-generation nucleoside and nucleotide analogues against lamivudine-resistant HBV. Antivir Ther 2005; 10:625-633.

49. Brunelle MN, Jacquard AC, Pichoud C, Durantel D, Carrouee-Durantel S, Villeneuve JP, et al. Susceptibility to antivirals of a human HBV strain with mutations conferring resistance to both lamivudine and adefovir. Hepatology 2005;41:1391-1398.

50. Ghany MG, Ayola B, Villamil FG, Gish RG, Rojter S, Vierling JM, Lok AS. Hepatitis B virus S mutants in liver transplant recipients who were reinfected despite hepatitis B immune globulin prophylaxis. Hepatology 1998;27: 213-222.

51. Andreone P, Caraceni P, Grazi GL, Belli L, Milandri GL, Ercolani G, et al. Lamivudine treatment for acute hepatitis B after liver transplantation. J Hepatol 1998;29:985-989.

52. Perrillo RP, Wright T, Rakela J, Levy G, Schiff E, Gish R, et al. A multicenter United States-Canadian trial to assess lamivudine monotherapy before and after liver transplantation for chronic hepatitis B. Hepatology 2001;33:424432. 